ORIGINAL ARTICLE

\title{
Assessing the level of Happiness among dental students of Pakistan: Web-based study
}

\author{
BEENISH FATIMA ALAM ${ }^{1}$, TALIB HUSSAIN ${ }^{2}$, SAMAN TAUQIR ${ }^{3}$, SAQIB ALI ${ }^{4}$, ARQAM NAJMI ${ }^{5}$, SIKANDAR JAVED \\ BAJWA ${ }^{6}$ \\ ${ }^{1}$ Assistant Professor Department of Oral Biology, Bahria University Medical \& Dental College, Karachi \\ ${ }^{2}$ Associate Professor Department of Oral biology, Women Medical \& Dental College, Abbottabad \\ ${ }^{3}$ Department of Physiology, Rehman College of Dentistry, Peshawar \\ ${ }^{4}$ Department of Biomedical Dental Sciences, College of Dentistry, Imam Abdulrahman Bin Faisal University, Dammam, Saudi Arabia \\ ${ }^{5}$ Department of Dental Materials, Bahria University Medical \& Dental College, Karachi \\ ${ }^{6}$ Associate Professor Department of Oral Biology, Lahore Medical \& Dental College, Lahore \\ Correspondence to Dr Sikandar Javed Bajwa Email sikandar.bajwa15@gmail.com Cell: 03334761848
}

\begin{abstract}
Background: Dental students in Pakistan suffer greatly from unusual distress and are unable to maintain happiness from the start of first year to final year. They are deprived from maintaining their mental wellbeing and happiness. There is lack of evidence Oxford happiness inventory $(\mathrm{OHI})$ evaluation among the students.

Aim: To detect the level of happiness in dental students from different professional years.

Methods: A cross-sectional study in Bahria University Medical and Dental College was carried out. Dental students were enrolled from first year to final year using purposive sampling method.

Results: This study included females 209, and 55 males. Majority of students (48.5\%) belonged to 18-20 years age group followed by $21-22$. About $50 \%$ students were from $1^{\text {st }}$ year BDS, followed by $2^{\text {nd }}$ year $(28 \%)$. Question assessing happiness of students, $30.9 \%$ male students and $35.4 \%$ female's students moderately agreed.

Conclusion: The study concludes that overall dental students had an average level of happiness. It is necessary that all the dental educationists in any institution should work with close association to psychologists, there shall be different student services provided and student supporting groups shall be encouraged.

Keywords: Oxford Happiness Questionnaire, happiness, well-being, students,
\end{abstract}

\section{INTRODUCTION}

Mental health and positive psychology are interconnected with happiness which has been in discussion during the recent years ${ }^{1}$. Happiness is said to be 'the quality or state of being happy or to be satisfied that something is good or right; not anxious'2. An inner state of successfulness and fullness that indicates gratification at the lowly end of the order and fierce enjoyment at the high end of the scale, happiness is a reflection of one's subjective well-being and their quality of life ${ }^{3}$. Being happy boosts the aptness of an individual, it tends to make one think positively, ensuring accomplishments, setting goals and exploring options ${ }^{4}$, it ameliorates individual ability to work efficiently in a team ensuring success in the workplace ${ }^{5}$. Happiness makes an individual to perceive, elucidate, and redesign life events in many ways compared to an unhappy person. It is influenced by different social contexts which includes individual cultures, religious beliefs, social relationships, social norms and values which shapes the meaning we give to things all these attributes increases one's ability to make choices ${ }^{4,5}$. Studies have suggested that happy people are more likely to be victorious at their workplace, they interact positively with their work team and pursue new life goals ${ }^{6}$.

Happiness is considered to be the key component in maintaining good quality of life ${ }^{6}$. Previously happiness was studied to in probe mental health as it is one of the top valued subjects in human life. Thus later in $20^{\text {th }}$ century it became an area of research to investigate positive

Received on 13-01-2021

Accepted on 21-05-2021 psychology related to human well-being and special assessment tools were developed to evaluate the happiness ${ }^{7}$. Any profession that provides job security is considered to be one of the most prominent indicator to measure careers success ${ }^{8}$ which evidently contributes to happiness of an individual (the experience of positive affect) ${ }^{5}$. Regarding this milieu, dentists are declared to have fortunate careers however; the reports regarding sodality of dental career and happiness are not enough.

Dental profession is associated with many health concerns which includes physical and mental tiredness, various psychological stressors (e.g., managing time, staff and patients' behaviors), pressure to make money along with emotional fatigue and burnout, all leading to poor mental health coupled with low level of performance ${ }^{9}$. Studies from different devolving and well developed countries have rated dentistry to be a demanding, pressured and hazardous profession ${ }^{10}$. It is highlighted in some researches that medical and dental students are supposedly more stressed but their psychological behavior is equally inclined towards happiness and stress simultaneously ${ }^{11}$.

A limited number of studies have determined happiness among dentists ${ }^{11,12}$. There is no current reported literature on the levels of happiness among undergraduate dental students across the nation.

Therefore, the current study attempts to address the gap by evaluating the level of happiness of dental students and how happiness could be consistent to emotional well being and one's own life satisfaction. 


\section{MATERIALS AND METHOD}

This cross-sectional study was carried out at Bahria University. All the participants were well informed about the research objective; their participation in study was voluntary and anonymous. Dental students enrolled from first year to final year were included using purposive sampling method. The students who gave their consent and provided responses were added to the study. This study duration was Sep -Dec 20.

Due to the current Pandemic an online survey form was formulated using Google Docs. Consent form was attached with it and confidentiality of the information was assured. The link of the questionnaire was shared with the students via WhatsApp, Facebook, Linkedln and other social media sites. The link was shared through all the main sources of communication to reach many students. After their agreement to the survey, they first filled the demographic detail, followed by set questions formulated using of Oxford Happiness Scale.

Initially demographic information was required which included age, gender, year of study educational level. Questions related to family income, and family structure was also asked. Rest of the questions were focused on Oxford Happiness Questionnaire that is a 29 questionsbased survey which aims at utilizing a six-point rating scale of agreement ranging from 1 (strongly agree) to 6 (strongly disagree). Reliability for this scale was found to be $\alpha 0.92$.

Data Analysis: Data was analyzed using SPSS (v 23) for Windows. In this study, descriptive statistics (average, standard deviation, frequency) while for the inferential statistics Chi square test and Fischer Exact test were used.

\section{RESULTS}

This study included females $n=209$, and $n=55$ males. Majority of students (48.5\%) belonged to $18-20$ years age group followed by $21-22$ being $43.5 \%$. About $50 \%$ students were from $1^{\text {st }}$ year BDS, followed by $2^{\text {nd }}$ year $28 \%$. About $50 \%$ of the female and $29 \%$ of male students moderately agreed not being pleased with the way they were. Regarding waking up feeling rested, $29 \%$ females and $25 \%$ males moderately disagreed with this.

Query regarding not having happy memories of past, $45.3 \%$ females and $38.6 \%$ males demonstrated slightly disagreement with this. Question regarding not being pleased with the way I am; $24 \%$ of final year and $23 \%$ of first year students slightly disagreed with this, while $41 \%$ of the third year students slightly agreed with this. (Table 2)

Table 1: Demonstrating the demographics of the dental students

\begin{tabular}{|l|l|l|}
\hline Gender & $\mathbf{n}$ & \%age \\
\hline Male & 55 & 20.8 \\
\hline Female & 209 & 79.2 \\
\hline Total & 264 & 100.0 \\
\hline Age (years) & 128 & 48.5 \\
\hline $18-20$ years & 115 & 43.6 \\
\hline $21-22$ years & 21 & 8.0 \\
\hline $23-24$ years & 264 & 100.0 \\
\hline Total & 131 & 49.6 \\
\hline Year at Dental College & 74 & 28.0 \\
\hline $1^{\text {st }}$ year & 22 & 8.3 \\
\hline $2^{\text {nd }}$ year & 37 & 14.0 \\
\hline $3^{\text {dd }}$ year & 264 & 100.0 \\
\hline $4^{\text {th }}$ year & \multicolumn{2}{|l|}{} \\
\hline Total & \multicolumn{2}{|l|}{} \\
\hline
\end{tabular}

Table 2: Exhibits association between the students and questions

\begin{tabular}{|c|c|c|c|c|c|}
\hline${ }^{\star \star}$ I don't feel particularly pleased with the way I am & $1^{\text {st }}$ year & $2^{\text {nd }}$ year & $3^{\text {rd }}$ year & $4^{\text {th }}$ year & P-value \\
\hline Slightly disagree & $30(22.90 \%)$ & $16(21.60 \%)$ & 0 & $9(24.30 \%)$ & \multirow{6}{*}{0.07} \\
\hline slightly agree & $20(15.30 \%)$ & $14(18.90 \%)$ & $9(40.90 \%)$ & $8(21.60 \%$ & \\
\hline moderately agree & $14) 10.70 \%)$ & $5(6.80 \%)$ & $4(18.20 \%)$ & $4(10.80 \%)$ & \\
\hline strongly agree & $15(11.50 \%)$ & $14(18.90 \%)$ & 0 & $6(16.20 \%)$ & \\
\hline moderately disagree & $41(31.30 \%)$ & $18(24.30 \%)$ & $2(9.10 \%)$ & $8(21.60 \%)$ & \\
\hline strongly disagree & $11(8.40 \%)$ & $7(9.50 \%)$ & $7(31.80 \%)$ & $2(5.40 \%)$ & \\
\hline \multicolumn{6}{|l|}{${ }^{\star \star}$ I rarely wake up feeling rested } \\
\hline Slightly disagree & $10(7.60 \%)$ & $8(10.80 \%)$ & $4(18.20 \%)$ & $6(16.20 \%)$ & \multirow{6}{*}{0.004} \\
\hline slightly agree & $19(14.50 \%)$ & $7(9.50 \%)$ & $3(13.60 \%)$ & $6(16.20 \%$ & \\
\hline moderately agree & $29(22.10 \%)$ & $13(17.60 \%)$ & $7(31.80 \%)$ & $2(5.40 \%$ & \\
\hline strongly agree & $20(15.30 \%)$ & $14(18.90 \%)$ & $3(13.60 \%)$ & $8(21.60 \%)$ & \\
\hline moderately disagree & $35(26.70 \%)$ & $22(29.70 \%)$ & $5(22.70 \%)$ & $10(27 \%)$ & \\
\hline strongly disagree & $18(13.70 \%)$ & $10(13.50 \%)$ & 0 & $5(13.50 \%)$ & \\
\hline \multicolumn{6}{|l|}{${ }^{\star \star}$ I do not have particularly happy memories of the past } \\
\hline Slightly disagree & $56(42.70 \%)$ & $30(40.50 \%)$ & $10(45.50 \%)$ & $16(43.20 \%)$ & \multirow{6}{*}{0.107} \\
\hline slightly agree & $19(14.50 \%)$ & $11(14.90 \%)$ & $4(18.20 \%)$ & $7(18.90 \%)$ & \\
\hline moderately agree & $14(10.70 \%)$ & $6(8.10 \%)$ & $7(31.80 \%)$ & $4(10.80 \%)$ & \\
\hline strongly agree & $20(15.30 \%)$ & $8(10.80 \%)$ & $1(4.50 \%)$ & $4(10.80 \%)$ & \\
\hline moderately disagree & $11(8.40 \%)$ & $12(16.20 \%)$ & 0 & $5(13.50 \%)$ & \\
\hline strongly disagree & $11(8.40 \%)$ & $7(9.50 \%)$ & 0 & $1(2.70 \%)$ & \\
\hline \multicolumn{6}{|l|}{${ }^{\star *}$ I don't feel particularly healthy } \\
\hline Slightly disagree & $30(22.90 \%)$ & $16(21.60 \%)$ & 0 & $9(24.30 \%)$ & \multirow{6}{*}{0.003} \\
\hline slightly agree & $20(15.30 \%)$ & $14(18.90 \%)$ & $9(40.90 \%)$ & $8(21.60 \%)$ & \\
\hline moderately agree & $14(10.70 \%)$ & $5(6.80 \%)$ & $4(18.20 \%)$ & $4(10.80 \%)$ & \\
\hline strongly agree & $15(11.50 \%)$ & $14(18.90 \%)$ & 0 & $6(16.20 \%)$ & \\
\hline moderately disagree & $41(31.30 \%)$ & $18(24.30 \%)$ & $2(9.10 \%)$ & $8(21.60 \%)$ & \\
\hline strongly disagree & $11(8.40 \%)$ & $7(9.50 \%)$ & $7(31.80 \%)$ & $2(5.40 \%)$ & \\
\hline
\end{tabular}

Majority of the students from all years demonstrated moderate disagreement with the question of rarely waking up feeling rested. Similarly majority of the students from $1^{\text {st }}$ year to final year slightly disagreed with the question of not 
having happy memories of past. Question related to gap between what I would like to do and what I have done exhibited moderate disagreement from all the students. Question regarding not feeling healthy, $31 \%$ of $1^{\text {st }}$ year, $24 \%$ of second year moderately disagreed with this, $41 \%$ of third years slightly agreed, while $24 \%$ of final years slightly disagreed with this. Questions related to not having fun with other people, majority of the students responded by slightly agreeing with this statement (Table 2).

\section{DISCUSSION}

Dentistry is considered among one of the prestigious and enriching professions, it is a stressful job associated with various physical and mental stress that affects a dentist's life ${ }^{13,14}$. Studies related to the level of happiness among dental students are quite rare worldwide ${ }^{6}$. Happiness imparts different effects on an individual, which includes positive attitudes towards life, high self-concept, increase of vitality, good mental health status; and higher level of physical performance ${ }^{15,16}$.

Overall, the dental students surveyed in our study showed moderate levels of happiness; $30.9 \%$ male students and $35.4 \%$ female. Dentists from Peru, Croatia and Serbia when assessed for their happiness levels, their happiness scores were noted to be quite high, while low happiness scores were recorded for dentists of Iraq, Yemen and Syria. This discrepancy might be related to a large variation in socio-economic framework, cultural environment and varied working environments ${ }^{17}$. Studies have reported findings in healthcare workers which were similar to our study ${ }^{18}$.

Present study reported that most of the $3^{\text {rd }}$ and $4^{\text {th }}$ year students were not happy with the way they were while the level of responses were same for both the genders. A study conducted by Moghadam $M$ et $\mathrm{a}^{19}$ among the Taif University medical students, in Saudi Arabia (45.6\%) of the students responded being happy. The findings of Alshehri et $\mathrm{al}^{20}$ showed that $(56.77 \%)$ of females were more unhappy as compared to males (52.5\%) although the reported difference was statistically in-significant ${ }^{20}$. They observed gender differences in overall scores. Studies conducted by Blasius $\mathrm{JJ}$ et $\mathrm{al}^{21}$ and Keshavarz et al have identified a positive relationship between the happiness scores and female gender, they suggest that the females are generally more content with their working environment ${ }^{22}$. On the other hand Danesh ${ }^{23}$ and Solymani's et $a^{\beta}$ reported no significant relationship between gender and happiness in their studies. However, the study by Solymani's et al., men had achieved high scores regarding life satisfaction while $31.6 \%$ of the male respondents of our study disagreed when they were asked if they were not pleased with the way they were ${ }^{9}$.

Students from different professional years were asked regarding having happy memories of the past majority of the students responded positively (Table 3). Happy memories were highest in the $3^{\text {rd }}$ and final year students' students, this might be due to the fact that they have been involved in treating patients and received patient gratitude from their work. Moreover it can be accredited to the increasing age and experience that is related with increased happiness. Similarly a study by RB Baran found high happiness levels in practicing dentists practicing from more than 10 years $^{24}$. Similarly, Jain et al., found that the level of happiness in dentists is directly corelated with increasing experience of the field, graduate and postgraduate degree ${ }^{25}$.

Most of the final year students reported rarely waking up feeling completely rested during their time at the medical school (Table 4). It can be attributed to the fact that most of the final year students are under exam stress, they have to think about the career. Most of the final year course includes clinical rotations this combined with the pressure to cover up course on time can be a reason causing stress. A study by AA Surani reported that most of the Pakistani medical students $(40 \%)$ had poor sleep quality during their medical career ${ }^{26}$. Some other factors associated with disturbed sleep might be different clinical rotations and early class timings which can cause sleep deprivation across the study year ${ }^{27}$.

Majority of the third years agreed upon not feeling healthy, these results are in contrast from the study led on Iranian student where they found that those medical students who exercised regularly were generally happier ${ }^{28}$. Exercise tends to increase the level of self-esteem and reduces the depression ${ }^{29,30}$.

The level of happiness, in dental students has an impact on their performance as it may be reflected in selfcare or patient care. Suggesting an urgent need for different training programs for stress management and attaining professional satisfaction. The present study is important as it explores the subjective well-being and happiness of undergraduate dental students which might affect their life and professional performances. A key strength of the study is that it explores the level of happiness using a standard scale. Well-designed studies shall be carried out to explore, in depth, subjective and objective responses obtained from a larger and randomly selected sample.

\section{CONCLUSION}

The study concludes that overall dental students showed a moderate level of happiness, psychological well-being and satisfaction with life. It is necessary that all the dental educationists in any institution shall work closer to psychologists, there shall be different student services provided and student supporting groups shall be encouraged. The issue of satisfaction and happiness among dental students shall be addressed in the nation to help increase happiness levels, which will ultimately improve their job performances.

Limitations: Due to the anonymity of the current study, we were not able to recognize those participants who responded negatively. Since, survey was conducted in only one dental school, the results may not be generalizable to students in other dental schools. Programs needs to be conducted how to provide a positive and supportive environment for students.

\section{REFERENCES}

1. Cheng $\mathrm{H}$, Furnham A. Attributional style and personality as predictors of happiness and mental health. Journal of Happiness Studies. 2001;2(3):307-27. 
2. Averill JR, More TA. Happiness. 1993.

3. Diener E, Emmons RA, Larsen RJ, Griffin S. The satisfaction with life scale. Journal of personality assessment. 1985;49(1):71-5.

4. Diener E, Biswas-Diener R. Will money increase subjective well-being? Social indicators research. 2002;57(2):119-69.

5. Boehm JK, Lyubomirsky S. Does happiness promote career success? Journal of career assessment. 2008;16(1):101-16.

6. Bryson A, MacKerron G. Are you happy while you work? The Economic Journal. 2017;127(599):106-25.

7. Lu L, Shih J. Personality and happiness: Is mental health a mediator? Personality and individual differences. 1997;22(2):249-56.

8. Hall DT, Chandler DE. Psychological success: When the career is a calling. Journal of Organizational Behavior: The International Journal of Industrial, Occupational and Organizational Psychology and Behavior. 2005;26(2):15576.

9. Hill K, Burke F, Brown J, Macdonald E, Morris A, White D, et al. Dental practitioners and ill health retirement: a qualitative investigation into the causes and effects. British dental journal. 2010;209(5):E8-E.

10. Moore R, Brødsgaard I. Dentists' perceived stress and its relation to perceptions about anxious patients. Community dentistry and oral epidemiology. 2001;29(1):73-80.

11. Prazich MN. Happiness in dentistry. Northwest dentistry. 2011;90(5):35-7.

12. Kaipa S, Paul KK, Satpathy A, Epari V. Are dentists happy? A study among dental practitioners in coastal Andhra Pradesh using subjective happiness scale. Indian Journal of Dental Research. 2017;28(6):604.

13. Kobza J, Syrkiewicz-Świtała M. Job satisfaction and its related factors among dentists: A cross-sectional study. Work. 2018;60(3):357-63.

14. Collin V, Toon M, O'Selmo E, Reynolds L, Whitehead P. A survey of stress, burnout and well-being in UK dentists. British dental journal. 2019;226(1):40-9.

15. Lyubomirsky S, King L, Diener E. The benefits of frequent positive affect: Does happiness lead to success? Psychological bulletin. 2005;131(6):803.

16. . .!!! INVALID CITATION !!!

17. Goetz K, Campbell S, Broge B, Dörfer C, Brodowski M, Szecsenyi J. The impact of intrinsic and extrinsic factors on the job satisfaction of dentists. Community dentistry and oral epidemiology. 2012;40(5):474-80.
18. Benzo RP, Kirsch JL, Nelson C. Compassion, mindfulness, and the happiness of healthcare workers. Explore. 2017;13(3):201-6.

19. Moghadam M, Rezaei F, Ghaderi E, Rostamian N. Relationship between attachment styles and happiness in medical students. Journal of family medicine and primary care. 2016;5(3):593.

20. Alshehri AA, Althobaiti SM, Alsaadi HD, Alnemari AK, Alyami $\mathrm{H}$, Alyami $\mathrm{M}$, et al. Subjective happiness assessment among taif university medical students. Am J Edu Res. 2016;4:1114.

21. Blasius JJ, Pae E-K. Work-pattern differences between male and female orthodontists. American journal of orthodontics and dentofacial orthopedics. 2005;128(3):283-90.

22. Keshavarz A, Vafaeian M. The study of the effective factors on the amount of happiness. 2007.

23. Danesh E. A COMPARISON OF HAPPINESS, PHYSICAL AND MENTAL HEALTH IN MALE AND FEMALE STUDENTS'MARRIED AND SINGLE OF UNIVERSITY. 2011.

24. Baran RB. Myers Briggs Type Indicator, burnout, and satisfaction in Illinois dentists. General dentistry. 2005;53(3):228-34; quiz 35.

25. Jain M, Mathur A, Joshi S, Goklani P, Kothari B, Rabu D. Job satisfaction assessment among dentists and dental auxiliaries in India. Internet J Dent Sci. 2009;7:2.

26. Surani AA, Zahid S, Surani A, Ali S, Mubeen M, Khan RH. Sleep quality among medical students of Karachi, Pakistan. J Pak Med Assoc. 2015;65(4):380-2.

27. Azad MC, Fraser K, Rumana N, Abdullah AF, Shahana N, Hanly PJ, et al. Sleep disturbances among medical students: a global perspective. Journal of clinical sleep medicine. 2015;11(1):69-74.

28. Lesani A, Mohammadpoorasl A, Javadi M, Ansari H, Fakhari A. Happiness among college students: a cross-sectional web-based study among iranian medical students. Biotechnology and Health Sciences. 2016;3(2).

29. Malekian A, Mohammadi Biabri S, Fattahi J, Safari A. The comparison of athlete and non-athlete students happiness of Kermanshah City. J Manag Sci. 2015;1(1):11-5.

30. Rivers C, Dilger J, editors. The Effects of Exercise on SelfEsteem, General Happiness, and Body Image. Big South Undergraduate Research Symposium (BigSURS). 2015. 